\title{
Trophic structure of a bathyal benthopelagic boundary layer community south of the Balearic Islands (southwestern Mediterranean)
}

\author{
J. E. Cartes ${ }^{1}$, F. Maynou ${ }^{1}$, B. Morales-Nin ${ }^{2}$, E. Massutí ${ }^{3}$, J. Moranta ${ }^{2}$ \\ ${ }^{1}$ Institut de Ciències del Mar (CSIC), Plaça del Mar s/n, 08039 Barcelona, Spain \\ ${ }^{2}$ Institut Mediterrani d'Estudis Avançats (IMEDEA - CSIC), Crta. Valldemossa, Km 7.5, 07071 Illes Balears, Spain \\ ${ }^{3}$ Direcció General de Pesca. Conselleria d'Agricultura i Pesca, Forners, 10, 07060 Palma de Mallorca, Illes Balears, Spain
}

\begin{abstract}
During 2 deep-sea oceanographic cruises carried out in October 1996 and May 1998, megafauna (fish and decapod crustaceans), suprabenthos, zooplankton, and environmental variables from the water column (fluorescence and light transmission) were simultaneously collected between 210 and $1752 \mathrm{~m}$ depth. Fish were the dominant megafaunal taxon in biomass along the slope; decapod crustaceans were co-dominants at intermediate depths (between 402 and $710 \mathrm{~m}$ ). Suprabenthos and zooplankton attained their maximal biomass at intermediate depths, with deeper maxima detected for suprabenthos (between 802 and $1322 \mathrm{~m}$ ) than for zooplankton (between 402 and $802 \mathrm{~m}$ ). Fish and decapod biomass were weakly correlated with each other, and with the suprabenthoszooplankton biomass, fluorescence and light transmission. Significant correlations were, however, detected between the suprabenthos and zooplankton and their possible food-sources deduced from fluorometer and light transmission data, with different patterns depending on the distribution of each compartment (trophic level) in the water column and the sediment-water interface. Within a single taxon (crustaceans), size distribution for suprabenthos-zooplankton and megafaunal species followed opposite temporal patterns in our study. Among suprabenthos-zooplankton species, smaller specimens (recruitment) were detected in October 1996, coinciding with the highest fluorometer signals in the water column. The dominant phytoplankton/phytodetritus consumers (the euphausiid Euphausia krohni and the mysid Boreomysis arctica) showed clearer recruitment peaks during October than those species preying upon meiofaunal taxa (the amphipod Rhachotropis caeca, and the isopod Munnopsurus atlanticus). These results suggest that the influence of food input signals progressively decreases with increasing trophic level, and therefore the indirect effect of superficial production on top trophic levels is difficult to establish at least for the short time scales of our oceanographic surveys.
\end{abstract}

KEY WORDS: Benthic Boundary Layer · Deep-sea communities · Trophic levels $\cdot$ Trophic webs $\cdot$ Mediterranean Sea Resale or republication not permitted without written consent of the publisher

\section{INTRODUCTION}

Deep-sea communities have been described in a number of works, both from a faunistic and community structure perspective (Haedrich et al. 1980, Jumars \& Gallagher 1982, Hecker 1990, McClatchie et al. 1997, and references cited therein). Deep-water communi-

*E-mail: jcartes@icm.csic.es ties have received increasing attention because of the interest in new fishing grounds and fisheries at bathyal depths (Hopper 1994, Merrett \& Haedrich 1997). Despite the growing effort in the study of these communities, the dynamics of the bathyal Benthic Boundary Layer (BBL) is still far from being reasonably well understood. Excepting the intensive biological studies in the Rockall Trough on epifauna and infauna (Tyler 1988, Gage 1994, Tyler et al. 1994), temporal changes 
in deep-sea communities have been the objective of few studies, particularly on vagile megafauna, such as fish or crustaceans (Wenner \& Boesch 1979, Cartes et al. 1994, Stefanescu et al. 1994, among others).

Some studies quantitatively describe deep-water food webs and trophic balances both at multispecific and autoecological levels (Bulman \& Koslow 1992, Maynou \& Cartes 1997, 1998, Pakhomov et al. 1997, Cartes \& Maynou 1998). Also, some general schemes on the carbon cycle have been published for abyssal depths (Pfannkuche 1992, Smith 1992). Information is available on stomach contents of fish species in the deep sea (summarised in Gordon \& Mauchline 1990), which are the dominant megafaunal taxa. These studies have often focused on species of commercial interest (Bulman \& Koslow 1992, Cartes 1994) or on some well-diversified and characteristic families, such as the Macrouridae (Macpherson 1979). In general, there is still a lack of integral approaches that relate different compartments (trophic levels), and most studies also lack an approach which considers the influence of environmental factors on population structure and abundance. Environmental coupling is particularly well documented, even at a mesoscale level, for shallow water communities (Joselson \& Conley 1997). Among deep-sea organisms a rapid response to flux changes has been documented (Lochte \& Turley 1988, Graf 1989), particularly in foraminiferans (Gooday et al. 1992). It is argued that this signal progressively decreases when trophic level increases, and therefore meiobenthos is the compartment that is expected to show the most rapid response to changes in food inputs (Graf 1989, Gooday et al. 1992). Further, surface pigment concentrations and deep benthic macrofaunal biomass and diversity are well correlated at various temporal and spatial scales (Watts et al. 1992). However, the influence of surface productivity on the life history of macrofauna and megafauna remains almost unknown.

In the western Mediterranean, environmental conditions such as primary production and total particle flux show different temporal characteristics depending on the general features of the water mass (Estrada 1985, Buscail et al. 1990, Miquel et al. 1994). Our sampling was conducted during 2 different periods (spring and autumn) to observe possible seasonal variations. On the Catalan Sea slope, to the north of the study area, suprabenthos (= hyperbenthos) was a basic food source for top trophic levels, a conclusion derived from exhaustive dietary studies on dominant species such as the deep-water red shrimp Aristeus antennatus and the fishes Lepidion lepidion and Bathypterois mediterraneus (Cartes 1994, Carrasson et al. 1998, author's unpubl. data). In a preliminary budget of trophic balance at mid-slope depths, it was suggested that suprabenthos is responsible of ca $50 \%$ of the benthic production (Cartes \& Maynou 1998). Therefore, suprabenthos and zooplankton were sampled to obtain data on the food resource that may sustain deep demersal megafauna, basically composed by fish and decapod crustaceans. The present study is based on the simultaneous sampling of various trophic levels of deepwater communities, ranging from food sources (as deduced from fluorometer and light transmission readings) to macrofauna-zooplankton and megafauna. The objective is to identify and discuss possible relationships between the different compartments involved in the dynamics of bathyal trophic webs in the western Mediterranean.

\section{MATERIAL AND METHODS}

Characteristics of the sampling. As part of the research project 'Deep-Sea Fisheries' (ref. FAIR-CT950655), 2 oceanographic cruises (Q1 and Q2) were carried out south of the Balearic Islands (southwestern Mediterranean, Algerian Basin, Fig. 1) between $38^{\circ} 06^{\prime}$ to $38^{\circ} 49^{\prime} \mathrm{N}$ and $1^{\circ} 32^{\prime}$ to $1^{\circ} 49^{\prime} \mathrm{E}$. The Q1 sampling was performed in October 1996 and the Q2 sampling in May 1998. In both cruises, megafauna (mainly fish and decapod crustaceans), macrofauna (suprabenthos or hyperbenthos, see Mees \& Jones 1997) and zooplankton (mesozooplankton) were sampled. CTD profiles, including data on fluorometry and turbidity (light transmission), were also performed.

Megafauna was sampled in both cruises with an MTS (Maireta trawl system) bottom trawl equipped with 2 doors, a single trawl warp, $25 \mathrm{~m}$ long bridle, and $6 \mathrm{~mm}$ of codend mesh size, with a general size and structure similar to the OTSB-14, a commonly used trawl in deep-sea megafaunal studies (Merrett \& Marshall 1981). Thirty-three hauls were taken in October 1996 and 14 in May 1998. Suprabenthos and zooplankton were collected with a Macer-GIROQ sled and with a plankton net attached to the bottom trawl. The Macer-GIROQ sledge has 3 superimposed $40 \times 80 \mathrm{~cm}$ rectangular mouth apertures. The gear is equipped with a mechanical closing-opening system and effectively samples suprabenthos (plus associated zooplankton) only when the sledge runners contact the sea floor. The gear samples the near-bottom water up to $1.5 \mathrm{~m}$ above the bottom. Net mesh size was $500 \mu \mathrm{m}$. The area covered by the sledge for each haul was calculated from towed distance given by flowmeters located in the mouth of the nets. Further details on sledge sampling methods have been published elsewhere (Cartes \& Sorbe 1995, 1998). During May 1998 data were obtained with a small plankton net $(40 \times$ $60 \mathrm{~cm}$ mouth, $500 \mu \mathrm{m}$ mesh size) attached to the bot- 


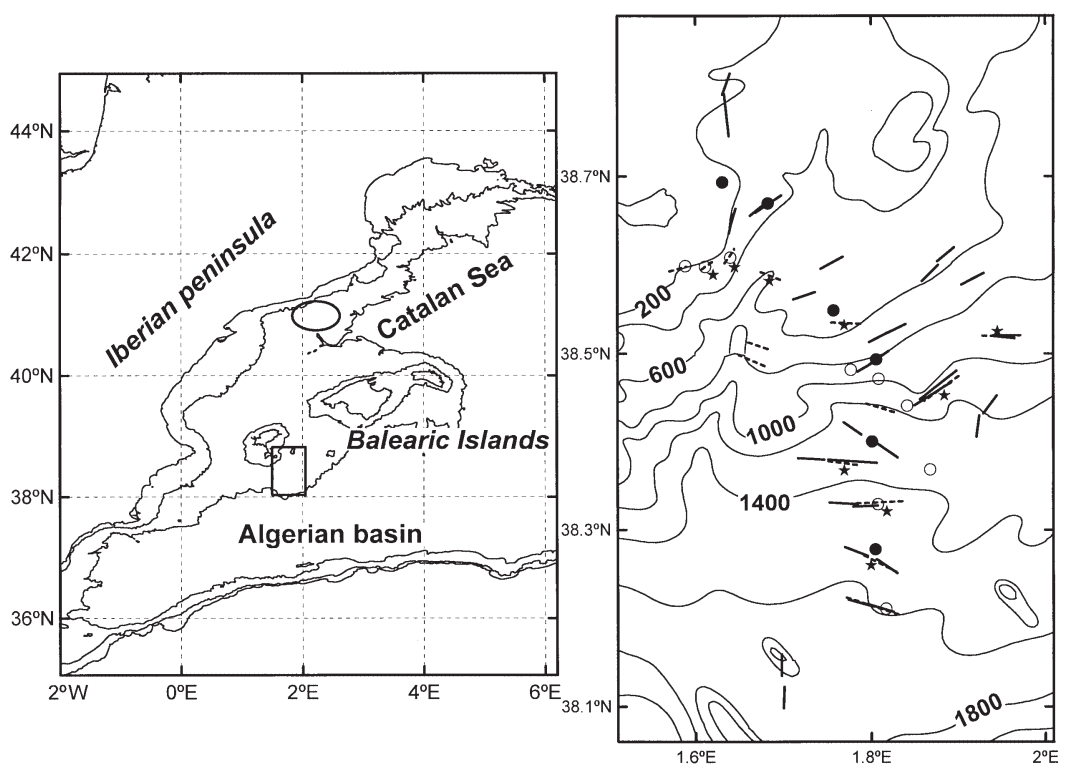

Fig. 1. Map of the sampling area off the SW Balearic Islands. (-): October 1996 trawl positions; (----): May 1998 trawl positions; CTD profiles: (•) October; (O) May; ( $\star$ ) trawl hauls in May 1998 cruise where a zooplankton net was attached. The area used for comparison in the Catalan Sea referred to in the text is also marked tom trawl. These samples have only a comparative value within the May 1998 cruise, although size frequencies can be compared with the data obtained from the October 1996 sampling because the same meshsize $(500 \mu \mathrm{m})$ and mouth apertures were used in the Macer-GIROQ sledge and in the plankton net (see also Cartes \& Sorbe 1993 for details).

Megafauna in the study area was comprised of mostly fish and large decapod crustaceans. The zooplankton of the sediment-water interface was composed of jellyfish (hydroids and siphonophores), mesopelagic decapods (mainly Sergestidae and Pasiphaeidae), euphausiids, ostracods, copepods, pteropods, cephalopods, chaetognaths, salps, pyrosomids and mesopelagic fish. The main components of suprabenthos in deep communities (see Cartes 1998) were nektobenthic decapods, peracarid crustaceans (mysids, amphipods, cumaceans, isopods and tanaidaceans), nebaliaceans and small benthopelagic fishes. A low overlap existed between the biomass of decapods and fish collected with the bottom trawl and the biomass of small decapods and fishes from the zooplankton or suprabenthos. The criteria used to segregate suprabenthic from zooplanktonic taxa were the different swimming capacities of organisms belonging to each compartment and the likely origin of the food source exploited by each compartment: Suprabenthos (=vagile macrofauna or hyperbenthos) comprises taxa that were almost exclusively caught in the lower net of the sledge, whereas zooplankton taxa were well represented in the 3 nets of the sledge with similar abundance. Likewise, zooplankton exploits mainly a food source originating in the mass flux of the water column and suprabenthos exploits the sediment or resuspended material on the sedimentwater interface. Fifteen suprabenthoszooplankton samples were taken during the 2 oceanographic cruises at depths ranging from 249 to 1597 m (6 in October 1996 and 9 in May 1998). During May 1998, the suprabenthos-zooplankton samples obtained with the small plankton net attached to the bottom trawl coincided with the location of the corresponding trawls (Fig. 1, Table 1).

Two CTD transects, using a Seabird25 model with an attached Seatech fluorometer and transmissometer, and comprising a total of 14 CTD profiles were performed in both cruises (5 in October, 9 in May, Fig. 1). Temperature, salinity, fluorometry and light transmission were recorded in each profile. In both cruises, CTD casts approximately coincided with the positions in which suprabenthos-zooplankton sampling were made.

Data analysis. The biomass ( $g$ wet $w \mathrm{t} \mathrm{m}^{-2}$ ) of fish and decapods was computed by an estimation of the area swept by the trawl. The area swept was computed by integrating the trawl path across the sea floor with an acoustic system (SCANMAR) yielding accurate measures of the trawl position and the net horizontal opening. The towing speed was kept at around 2.6 knots, while the trawled area varied from 2.36 to 8.14 ha. The sledge samples of suprabenthos and zooplankton were
Table 1. Characteristics of the suprabenthic sledge samples obtained during the Q1 (26 October 1996) cruise. During Q2 (May 1998), the locations of the suprabenthos-zooplankton samples obtained with a small plankton net attached to the bottom trawl coincided with that of the corresponding trawl hauls and are included in Fig. 1. All the samples were collected during daytime

\begin{tabular}{|cccc|}
\hline Station & Location & $\begin{array}{c}\text { Depth } \\
(\mathrm{m})\end{array}$ & $\begin{array}{c}\text { Area covered } \\
\left(\mathrm{m}^{2}\right)\end{array}$ \\
\hline Q1-1 & $38^{\circ} 50.00^{\prime} \mathrm{N}-1^{\circ} 36.43^{\prime} \mathrm{E}$ & $249-247$ & 709 \\
Q1-2 & $38^{\circ} 41.59^{\prime} \mathrm{N}-1^{\circ} 40.53^{\prime} \mathrm{E}$ & $400-398$ & 787 \\
Q1-3 & $38^{\circ} 33.73^{\prime} \mathrm{N}-1^{\circ} 46.93^{\prime} \mathrm{E}$ & $601-602$ & 861 \\
Q1-5 & $38^{\circ} 29.2^{\prime} \mathrm{N}-1^{\circ} 48.82^{\prime} \mathrm{E}$ & $809-802$ & 522 \\
Q1-6 & $38^{\circ} 24.47^{\prime} \mathrm{N}-1^{\circ} 48.39^{\prime} \mathrm{E}$ & $1204-1200$ & 897 \\
Q1-7 & $38^{\circ} 12.63^{\prime} \mathrm{N}-1^{\circ} 48.31^{\prime} \mathrm{E}$ & $1582-1594$ & 1047 \\
\hline
\end{tabular}


immediately fixed in buffered formaldehyde. Samples were blotted and weighed ( $\mathrm{g}$ WW) at the laboratory. In the October 1996 cruise, the surface swept by the sledge ranged between 709 and $1047 \mathrm{~m}^{2}$ (Table 1).

Fluorometer data (voltage) obtained in both cruises were re-calculated for comparative purposes. We considered the sum of values obtained by each $m$ interval in the water column as a rough estimate of the total fluorometry in the water column for each station. This value was obtained from the surface to the depth at which the sensory signal stabilised close to 0 (see profiles in Fig. 2). This depth varied between 141 and $186 \mathrm{~m}$ in October 1996 and between 106 and $175 \mathrm{~m}$ in May 1998. Light transmission was also estimated by station from all the values recorded by the transmissometer on the CTD. Two distinct estimates were used: (1) all data recorded in the entire water column, and (2) data recorded in the depth range comprising the maximum depth at which CTD was deployed (around 10 to $20 \mathrm{~m}$ above bottom) and $50 \mathrm{~m}$ above this level. This limit coincides with the upper limit of the BBL, which has been defined as the sediment-water interface where higher levels of biological activity (in comparison to midwater levels) are recorded (cf. Wishner \& Gowing 1992). Light transmission is inversely related to the beam attenuation coefficient and to suspended particle concentration for particles of a given grain size range (Baker \& Lavelle 1984, Puig \& Palanques 1998). The general aim in this study was to search for possible relationships between these environmental data and the biomass obtained for each biological compartment. The non-parametric Spearman correlation coefficient, a method based on rank order (Sokal \& Rohlf 1969), was used to test these relationships.

Specimens of the dominant species (in biomass) in our bathyal assemblages were selected for size-distribution comparison between the 2 seasons sampled. We used eucarid and peracarid crustaceans because they constitute the most diverse taxonomic group in our bathyal assemblages. Size frequency histograms were constructed for the selected species (megafauna and macrofauna) for both seasons. Cephalothorax length (mm CL) or total length (mm TL), depending on the species, were measured with an ocular micrometer using a stereomicroscope at 10 to $40 \times$ for the selected suprabenthos/zooplankton species. CL was measured from the tip of the rostrum to the posterior dorsal edge of the carapace, and TL from the tip of the rostrum to the end of the telson (both measures in lateral view). Cephalothorax length (mm CL) was measured in megafaunal decapod crustaceans.
Among the suprabenthos and zooplankton species, 5 dominant species belonging to different taxa and showing different biological features (size, life history, and swimming capability) were selected for size comparison between seasons. These species were the euphausiid Euphausia krohni representing zooplankton, and the mysid Boreomysis arctica, the amphipod Rhachotropis caeca, the isopod Munnopsurus atlanticus and the cumacean Procampylaspis armata representing suprabenthos. Among decapods of the upper continental slope, the dominant species were Plesionika heterocarpus and Parapenaeus longirostris. Plesionika martia was the most abundant species of the middle slope, while Aristeus antennatus and Acanthe-
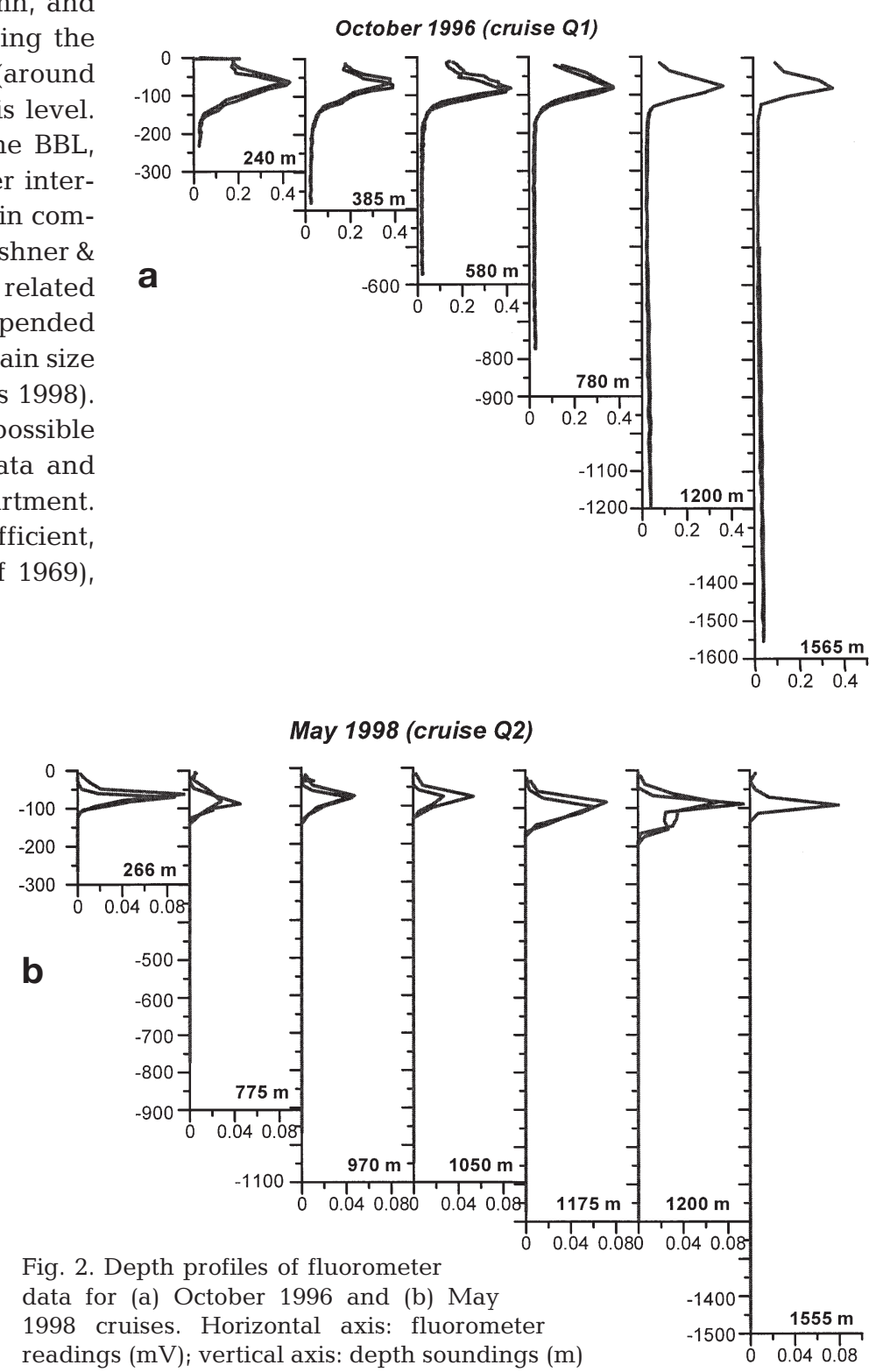
phyra eximia were the most abundant species on the lower slope. Although some crabs, such as Geryon longipes, may account for high biomass due to their large mean size, we did not select these slow-growing organisms due to their low density, low food consumption (Maynou \& Cartes 1998) and their presumably low production/biomass ratio. The mesopelagic species Sergia robusta was selected for this detailed study because it is a planktonic species.

Comparisons with the Catalan Sea area. We also discuss and compare the general trophic structure of the SW Balearic Islands with the trophic structure of the Catalan Sea, a relatively well-studied area in regard to food webs, ca $300 \mathrm{~km}$ to the north of our study site. We compare some aspects of 2 a priori contrasting areas, one being submitted to continental and advective influences (the Catalan Sea) and other with characteristics more closely resembling an opensea area (the SW Balearic Islands). This comparison is made by considering the biomass distributions and biomass ratios between the SW Balearic Islands (present results) and the Catalan Sea for different trophic levels. Relevant information for the Catalan Sea has been summarised in Figs. 8 \& 9. Megafaunal biomass (decapods and fish) results were obtained for the Catalan Sea with 2 similar bottom trawl models: Up to $800 \mathrm{~m}$, the megafauna of the Catalan Sea was sampled using the same bottom trawl as in the SW Balearic Islands (the MTS trawl) and from cruises performed in April-May and October (see details in Cartes et al. 1994). For depths below 900 and down to $2261 \mathrm{~m}$, the megafaunal biomass was estimated with an OTSB-14 bottom trawl, similar to the MTS, in cruises performed in June-July and October (see more details in Stefanescu et al. 1992). Suprabenthos/zooplankton were sampled in the Catalan Sea with the same model of suprabenthic sledge used in this study. Two types of comparisons are plotted in Fig. 9: (1) One was made by selecting data from the Catalan Sea obtained in similar conditions to those described for the October 1996 cruise in the water column, i.e., July 1992 (R4 cruise), July 1994 (BT2 cruise), October 1996 (Pr96 cruise: 12 October and 13 October 1996), and September 1998 (BBL2 cruise). (2) The other comprised only data from October 1996 and September 1998. The depth and seasonal variability can be reduced by choosing cruises performed at similar depths and similar periods for the 2 areas compared. However, no account can be made for the possible interannual variations in this type of studies due to the non-continuous nature of the data, but variations at this time scale cannot be ruled out, considering that sampling in the Catalan Sea was conducted up to $6 \mathrm{yr}$ before the sampling in the SW Balearic Sea.

\section{RESULTS}

\section{Basic oceanographic features}

Surface temperature was 17.2 to $17.5^{\circ} \mathrm{C}$ in May 1998 and around $21^{\circ} \mathrm{C}$ in October 1996 . Thermal stability $\left(13.3^{\circ} \mathrm{C}\right)$ was attained in the water column at depths between 159 and $190 \mathrm{~m}$ in May and between 101 and $132 \mathrm{~m}$ during October. CTD data from both cruises indicates that in October the general oceanographic conditions of the water mass resembled summer stratification (unpubl. data), whereas May 1998 was a transitional period in which the water mass was not stratified, more similar to winter conditions. Surface salinity oscillated between 36.1 and 37.3 psu in May and 37.6 and 37.8 psu in October.

Fluorometer readings (voltage) were higher in October 1996 than in May 1998 (Figs. 2a,b). No bathymetric trends were observed in October 1996 (Fig. 2a), while during May 1998, maxima were detected in profiles made on soundings between 178 and $420 \mathrm{~m}$ and ca $1200 \mathrm{~m}$ (9 stations between 178 and $1599 \mathrm{~m}$ soundings, Fig. 2b). Light transmission data (inverse to particle concentration in the water column) had a maximum at intermediate depths in May 1998, with a clear minimum on ca $400 \mathrm{~m}$ soundings in all the water column and at $50 \mathrm{~m}$ above bottom (mab). In October 1996, light transmission in the entire water column increased offshore beyond the station situated on $601 \mathrm{~m}$ and minimum values were only detected at ca $600 \mathrm{~m}$ close to the bottom (50 mab; Fig. 3). Such minima may reflect the crossing of frontal systems, oceanographic structures usually found in the shelf-slope break (Wang et al. 1988).

\section{Biomass distribution by depth and season}

Fish and decapods were the dominant megafaunal taxa in bottom trawl samples. Other invertebrate taxa (i.e. cephalopods, echinoderms) were secondary in these samples. Fish was the dominant megafaunal taxon in biomass along the slope, both during October 1996 and May 1998. Fish biomass was lowest at depths ranging from 402 to $694 \mathrm{~m}$ (October 1996) and 415 to 710 m (May 1998), which coincided with maximum biomass in decapod crustaceans (Fig. 4).

The suprabenthos reached maximum biomass values at intermediate depths, both in October 1996 (at 802 and at $1211 \mathrm{~m}$ ) and in May 1998 (between 908 and $1322 \mathrm{~m}$ depth). Zooplankton biomass was largest between 402 and $802 \mathrm{~m}$ in October 1996, while the largest values were found at 415 to $510 \mathrm{~m}$ in May 1998. Note that zooplankton were caught exclusively in the BBL (near bottom) during October 1996, but in May 


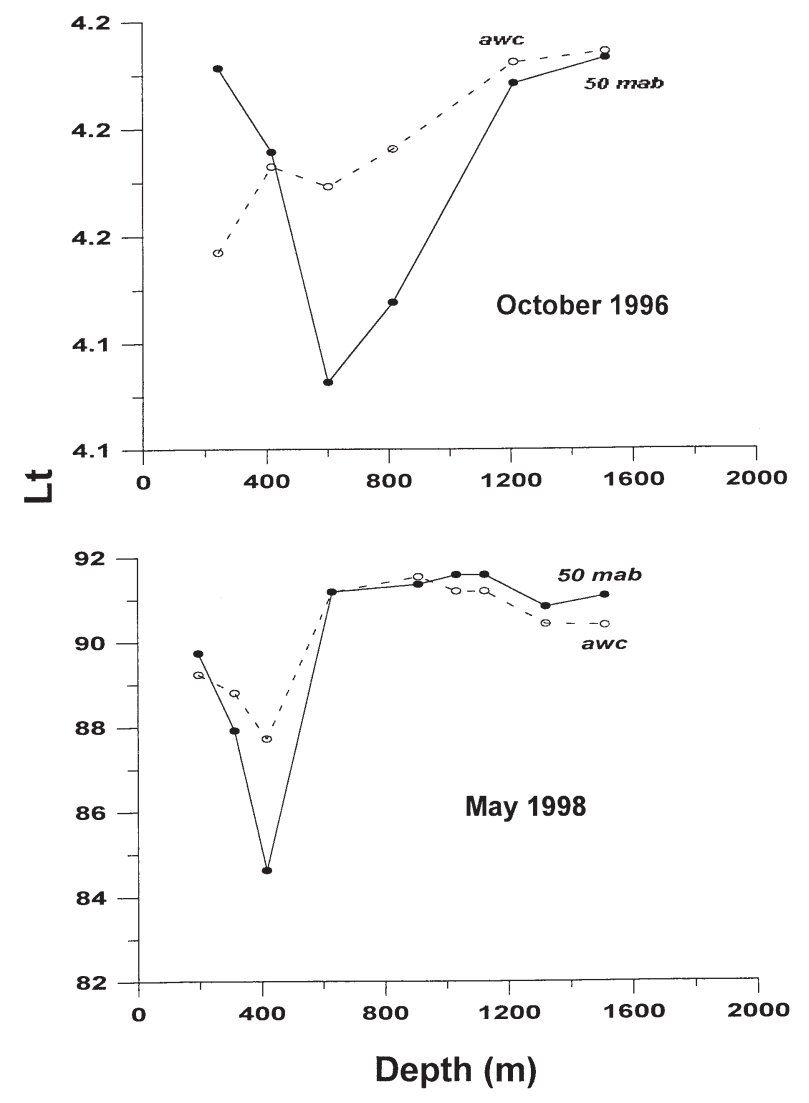

Fig. 3. Light transmission (Lt) plotted as a function of depth soundings. Transmissometer data was expressed as voltage units for October 1996, and \% of light transmission for May 1998. Data are shown considering all the water column (awc), and $50 \mathrm{~m}$ above the bottom (mab)

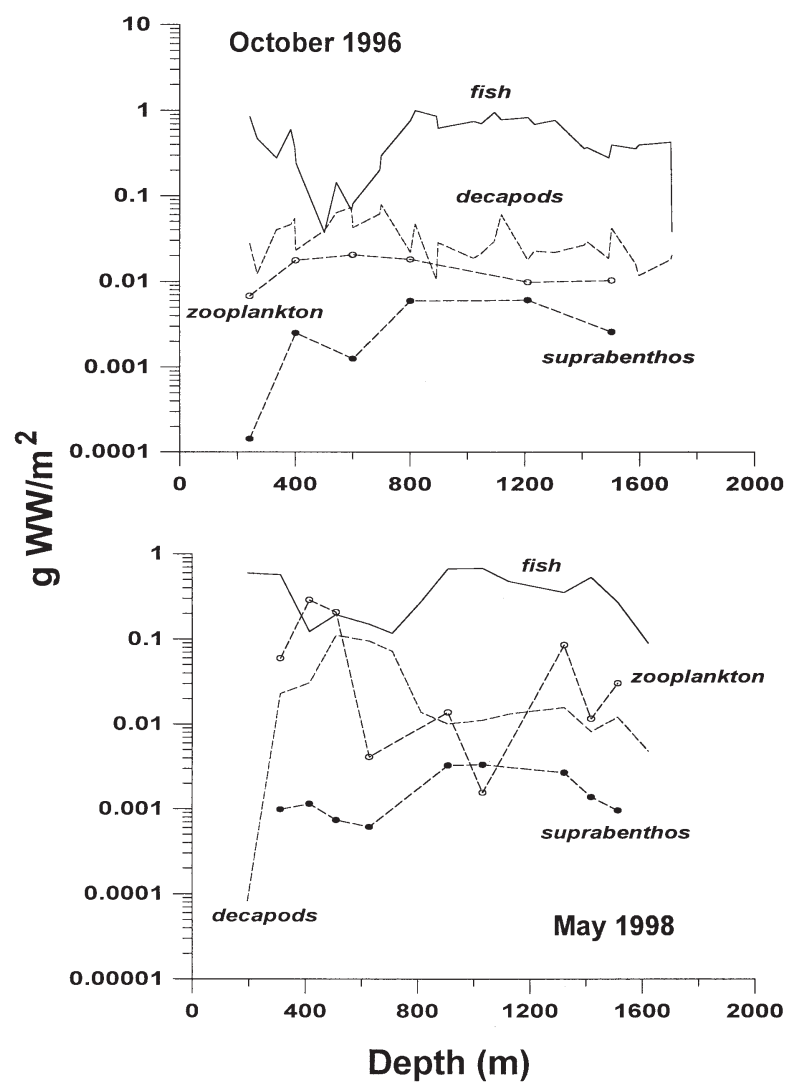

Fig. 4. Biomass distribution ( $\mathrm{g} \mathrm{WW} \mathrm{m}^{-2}$ ) for each biological compartment by depth for October 1996 (top) and May 1998 (bottom) cruises
Table 2. Correlations (non-parametric Spearman coefficient) between the biomass of the different compartments sampled in the Q1 (October 1996) and Q2 (May 1998) cruises; $\mathrm{n}=$ number of samples

\begin{tabular}{|c|c|c|c|c|c|c|c|c|c|}
\hline & \multicolumn{3}{|c|}{ Fish } & \multicolumn{3}{|c|}{ Suprabenthos } & \multicolumn{3}{|c|}{ Zooplankton } \\
\hline & $\mathrm{n}$ & $\mathrm{r}$ & $\mathrm{p}$ & $\mathrm{n}$ & $\mathrm{r}$ & $\mathrm{p}$ & $\mathrm{n}$ & $\mathrm{r}$ & $\mathrm{p}$ \\
\hline \multicolumn{10}{|l|}{ October 1996} \\
\hline Decapods & 31 & -0.285 & - & 6 & -0.714 & 0.11 & 6 & 0.314 & - \\
\hline Fish & & & & 6 & 0.143 & - & 6 & -0.829 & 0.04 \\
\hline Suprabenthos & & & & & & & 6 & 0.029 & - \\
\hline \multicolumn{10}{|l|}{ May 1998} \\
\hline Decapods & 14 & -0.464 & 0.09 & 9 & -0.733 & 0.02 & 9 & 0.517 & 0.15 \\
\hline Fish & & & & 9 & 0.733 & 0.02 & 9 & -0.533 & 0.14 \\
\hline Suprabenthos & & & & & & & 9 & -0.250 & - \\
\hline \multirow[t]{2}{*}{ Fish/decapods } & \multicolumn{3}{|c|}{ Upper slope } & \multicolumn{3}{|c|}{ Middle slope } & \multicolumn{3}{|c|}{ Lower slope } \\
\hline & $\mathrm{n}$ & $\mathrm{r}$ & $\mathrm{p}$ & $\mathrm{n}$ & $\mathrm{r}$ & $\mathrm{p}$ & $\mathrm{n}$ & $\mathrm{r}$ & $\mathrm{p}$ \\
\hline Oct 1996 & 6 & 0.086 & - & 6 & 0.600 & 0.21 & 19 & 0.251 & - \\
\hline May 1998 & - & - & - & - & - & - & 8 & -0.071 & - \\
\hline
\end{tabular}

1998 this compartment included organisms caught in the entire water column due to the non-quantitative method used, lacking a remote opening-closing system.

In most cases, the pair-wise relationships between the biomass of each compartment were not significant along the entire bathymetric range, but a few significant correlations are highlighted in Table 2: Fish and zooplankton biomass were negatively correlated $(r=-0.829)$ in October 1996, decapod and suprabenthos biomass were negatively correlated in May 1998 ( $\mathrm{r}=-0.733$ ) and nearly so with a similar value in October 1996, and fish and suprabenthos biomass were positively correlated ( $\mathrm{r}=$ 0.733) in May 1998. Fish and decapod biomass showed negative, albeit non-significant, correlations in both seasons. 
Within each continental slope level (upper: between 242 and $402 \mathrm{~m}$; middle: between 502 and $699 \mathrm{~m}$; and lower: between 802 and $1713 \mathrm{~m}$ ), no significant relationships were detected between fish and decapod biomass. Due to the low number of points available for suprabenthos/ zooplankton biomass, it was not possible to apply any tests within each slope level for these biological compartments.

The relationships between fluorescence values and fish, decapods, suprabenthos and zooplankton biomass were not significant during October 1996 (Table 3). In contrast, fluorescence and zooplankton distributions during May 1998 were significantly correlated (Table 3 ). Note that zooplankton in October 1996 were represented by those organisms collected in the 0 to $1.5 \mathrm{~m}$ sediment-water interface (sampled using the Macer-GIROQ sledge), while in May 1998 zooplankton included those organisms inhabiting the entire water column. Light transmission and zooplankton were negatively correlated for both October and May surveys (Table 3). Significant correlations were recorded in May both for entire water column transmissometer data and at $50 \mathrm{mab}$, while in October the correlation was only significant for the 50 mab data. In contrast to zooplankton, suprabenthos always showed positive correlations to transmissometer data, although the r obtained was only significant in October for all the water column data (Table 3).

Although fish and decapod biomass values were within the same order of magnitude in both seasons sampled (Fig. 5), some higher values were reached at specific bathymetric levels for each taxon in both cruises (Fig. 5). Fish biomass was higher at mid depths between 800 and 1300 m, especially in October 1996 . Decapod biomass attained maximum values at intermediate depths between $\sim 450$ and $800 \mathrm{~m}$, especially during May 1998, while decapod biomass was higher below 800 m during October 1996.

\section{Comparative size distribution for selected species}

Among suprabenthos/zooplankton species, Euphausia krohni and Boreomysis arctica showed peaks of small juvenile specimens in October 1996, which were absent or very scarce during May 1998 (Fig. 6). Rhachotropis caeca, Munnopsurus atlanticus, and Procampylaspis armata had similar proportions of smaller specimens in both seasons, although the smallest spec-

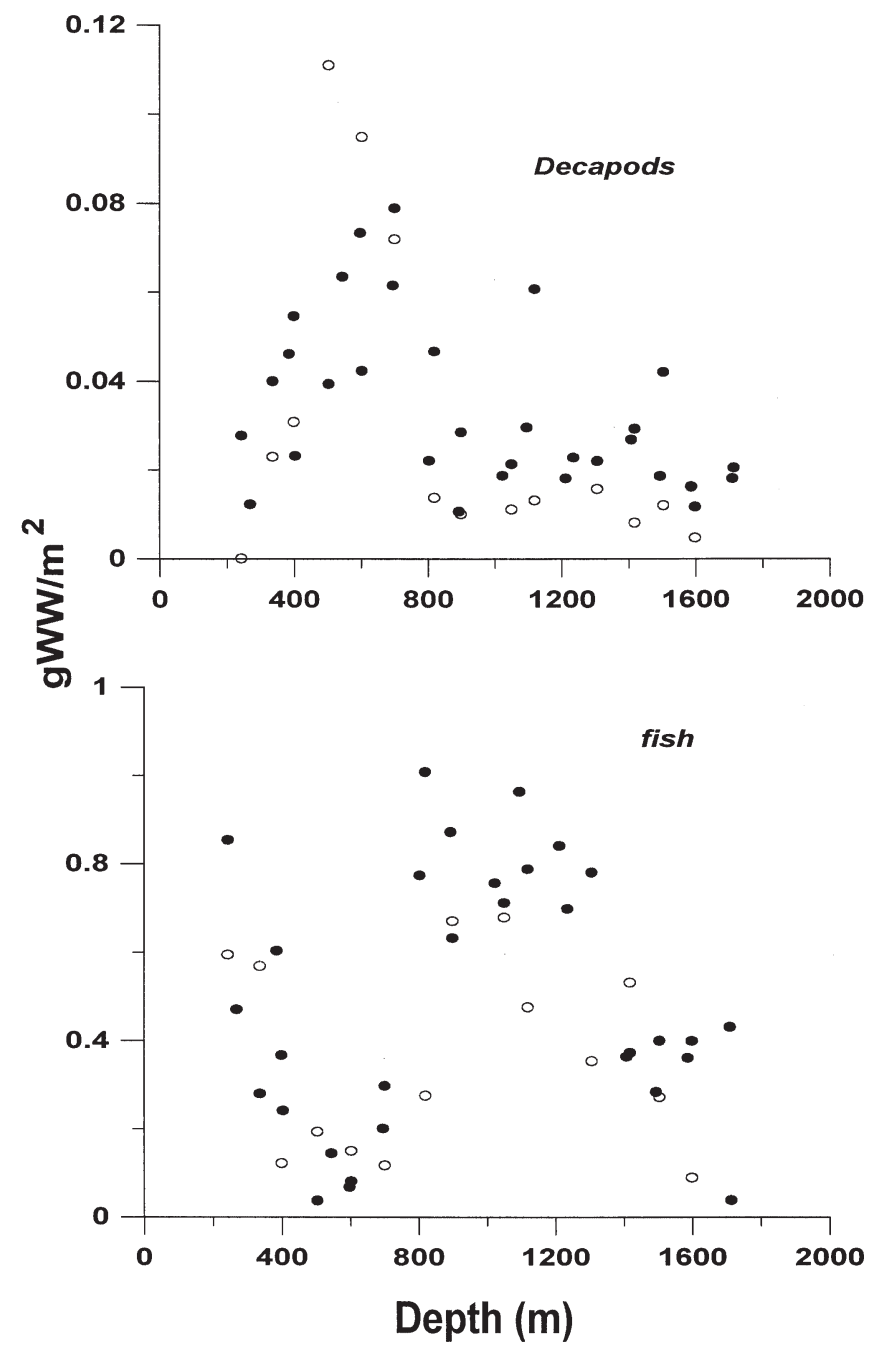

Fig. 5. Comparison of decapod crustacean and fish biomass in the October 1996 (•) and the May 1998 (०) cruises 
October 1996

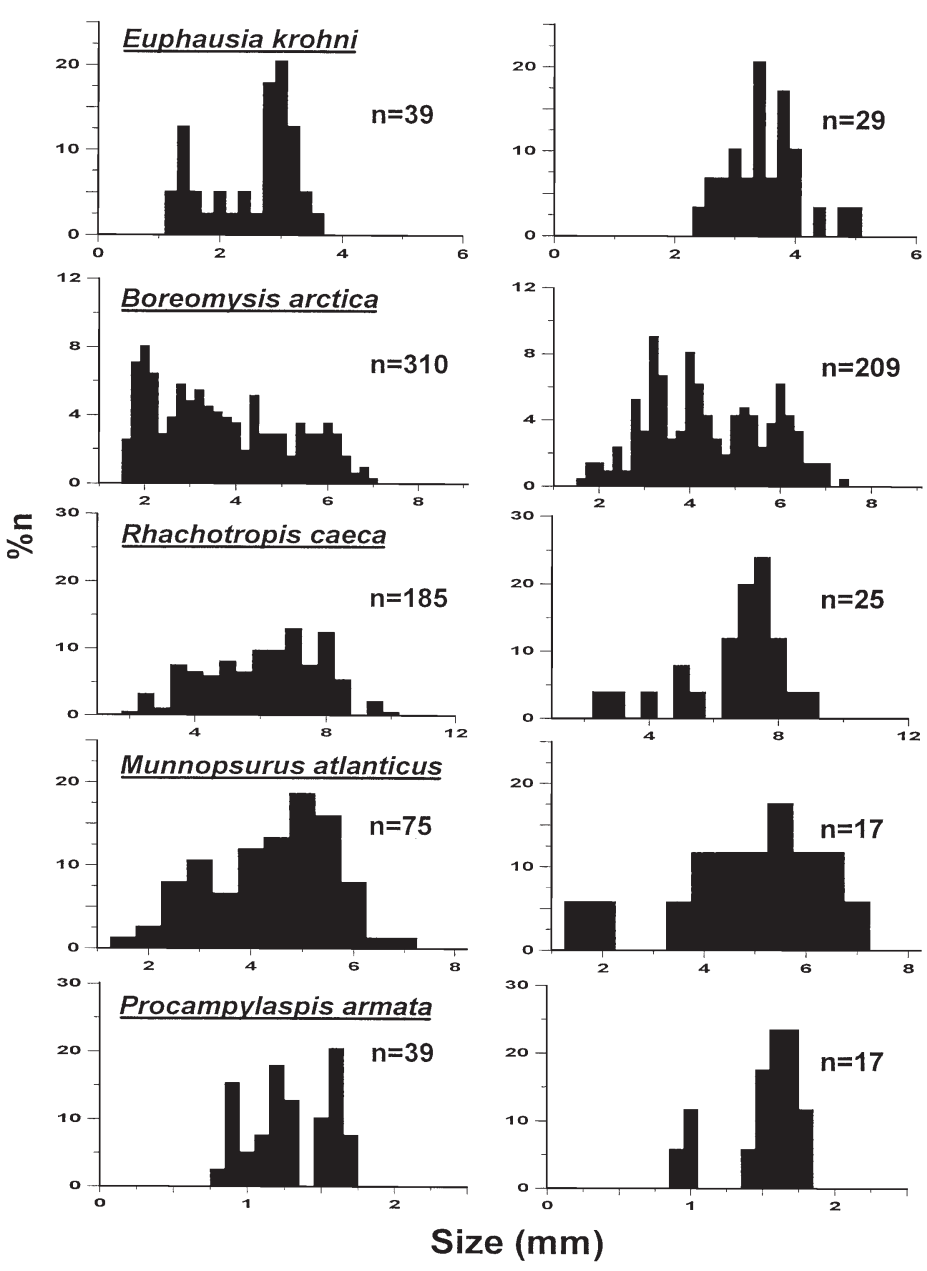

Fig. 6. Comparative size distribution of some dominant species of suprabenthos and zooplankton in the October 1996 and the May 1998 cruises. Size measured as CL (cephalic length, mm) for Euphausia krohni, Boreomysis arctica and Procampylaspis armata and as TL

(total length) for Rhachotropis caeca and Munnopsurus atlanticus showed maximum biomass on the upper slope and at around $1200 \mathrm{~m}$ in the Catalan Sea while decapods showed a biomass increase toward mid-slope levels (Fig. 8). The decrease in fish biomass at mid-slope levels of the SW Balearic Islands (at $\sim 400$ to $600 \mathrm{~m}$ in October and at $\sim 350$ to $800 \mathrm{~m}$ in May, Fig. 4) were not detected in the Catalan Sea in part probably due to a sampling gap. In the Catalan Sea, suprabenthos biomass showed higher levels than in the SW Balearic Islands, particularly at mid-slope levels around $600 \mathrm{~m}$ depth (cf. Figs. 4 \& 8). The suprabenthos/zooplankton ratio was always higher in the Catalan Sea, particularly on the middle slope (Fig. 9). In the Catalan Sea, this ratio was often close to or higher than 1, while in the SW Balearic Islands the ratio rarely attained 0.5. Furthermore, the suprabenthos/megafauna ratio was clearly higher on the Catalan Sea slope than on the SW Balearic Islands slope, particularly on the middle slope (Fig. 9).

\section{DISCUSSION}

A higher trophic dependence (coupling) was detected between suprabenthos-zooplankton and their possible food sources (here represented by fluorometry and light transmission data) than between suprabenthos-zooplankton and their predators or between the biomass of fish and decapod crustaceans. Within the limitations of our study, these results show that the significance of the relationships between compartments increases with decreasing trophic level.

The biomass of the 2 dominant megafaunal taxa in the study area (fish and decapods) were weakly correlated with each other, both within imens were often collected in October 1996 for these species. Higher proportions of adult (reproductive) specimens were detected in May 1998 for B. arctica.

An opposite trend can be observed in megafaunal decapods. All the dominant species at different bathymetric levels showed peaks of smaller individuals in May 1996 (Fig. 7), although this trend was less evident for the deepest-dwelling species (i.e. Acanthephyra eximia, Aristeus antennatus and Sergia robusta).

\section{Comparisons with the trophic structure of the Catalan Sea slope}

Biomass profiles have similar structure in both areas for fish and decapod crustaceans (Fig. 4a, Fig. 8). Fish each slope zone, and along the entire depth range studied, thus suggesting that these 2 groups of megafauna do not have a strong trophic dependence (in terms of prey/predator relationships) on each other. Probably both taxa are really within the same (or similar) trophic level as has been revealed by dietary studies (Macpherson 1977, 1979, Carrasson 1994, Cartes 1994, 1998, and references cited therein) and more recently by the study of $\delta^{15} \mathrm{~N}$ isotopic composition (authors' unpubl. data). The zonation of megafaunal assemblages in our study area roughly coincided with the depth boundaries where fish or decapod biomass switched dominance (Moranta et al. 1998, Maynou \& Cartes 2000). Thus, fish are clearly dominant in biomass over decapods at the upper (down to $400 \mathrm{~m}$ ) and the lower (below $~ 800$ to $900 \mathrm{~m}$ ) levels of the slope, 


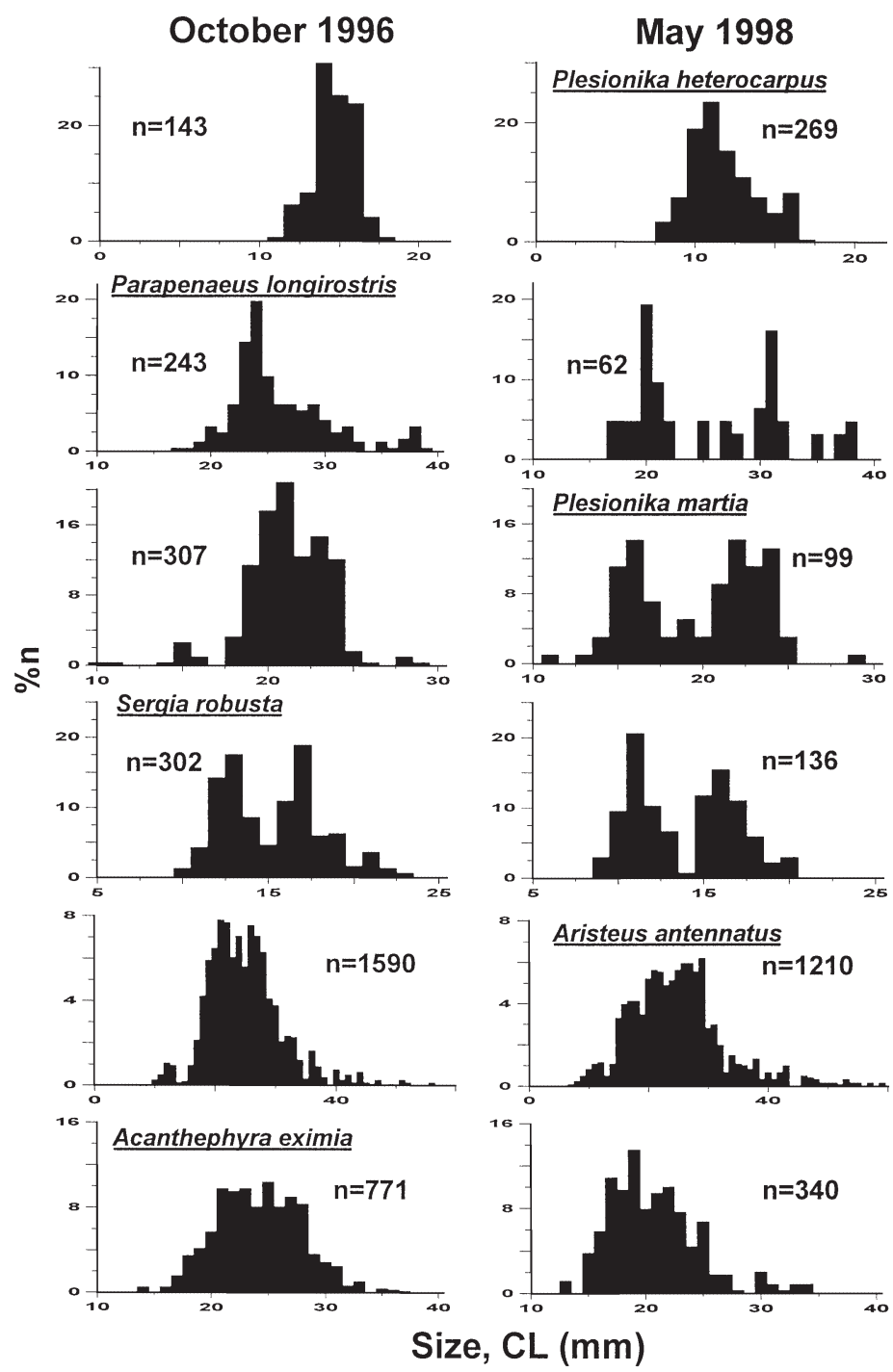

Fig. 7. Comparative size distribution (CL: cephalothorax length, $\mathrm{mm}$ ) of the dominant species of decapod crustaceans captured with bottom trawls in the October 1996 and the May 1998 cruises

while decapod crustaceans were co-dominant at midslope levels. The low correlations between fish and decapod biomass and their biomass shift as a function of depth, alternatively suggest that the trophic relationship between fish and decapods along the slope would probably be based more on a competitive exclusion due to the exploitation of similar food resources than on predator/prey relationships. In the same way, from detailed studies on fish diet from the neighbouring Catalan Sea (Macpherson 1977, 1979, Carrasson 1994, Cartes 1994, 1998), fish consume preferentially small mesopelagic decapods (i.e. Pasiphaeidae, Sergestidae), whereas some decapods that also consume fish prey almost exclusively on small mesopelagic Myctophidae and Cyclothone spp. Other important food items for fish and decapods are small infaunal crustaceans, preferentially Calocaris macandreae. However, all these prey groups make a scarce contribution to the total biomass of fish and decapods in our study because of their small size, which may explain the non-existent correlation detected between the 2 compartments. The variation of food-web structure with depth is probably of particular importance in structuring deep-bathyal Mediterranean communities, given that environmental characteristics are fairly constant below $200 \mathrm{~m}$ (thermal and saline stability: Fredj \& Laubier 1985).

Other explanations for the low correlation between fish and decapod biomass must be sought in the highly diversified diets (see Mauchline \& Gordon 1985, Cartes 1998, and references cited therein) of deep-water megafaunal predators. Highly diversified diets and complex trophic relationships conceptually place bathyal communities as trophic webs, while our pair-wise approach to test correlations between compartments seems more adequate to examine the linear (i.e., chain-like) trophic structure found in plankton communities. The different response time (coupling) by each compartment should likewise be borne in mind, so that peaks of abundance of different trophic levels may not occur simultaneously in the short time frame of an oceanographic survey.

We also detected low correlations between fish and decapod biomass and their respective poten-

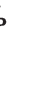

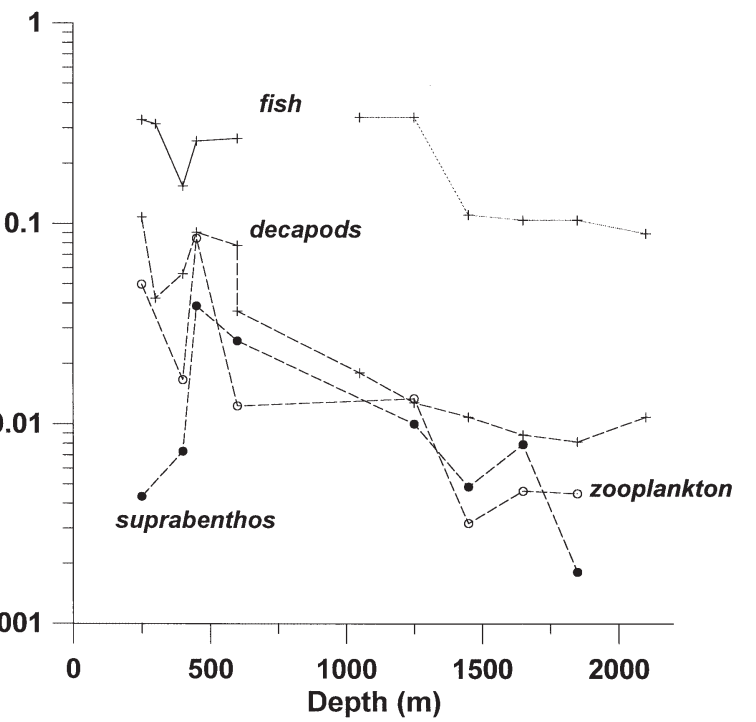

Fig. 8. Biomass distribution $\left(\mathrm{g} \mathrm{WW} \mathrm{m}^{-2}\right.$ ) by depth in the Catalan Sea (NW Mediterranean), north of the SW Balearic Islands. Data based on cruises performed during 1990-1995 (see more detailed information in 'Material and methods', and in Stefanescu et al. 1992, Cartes et al. 1994) 

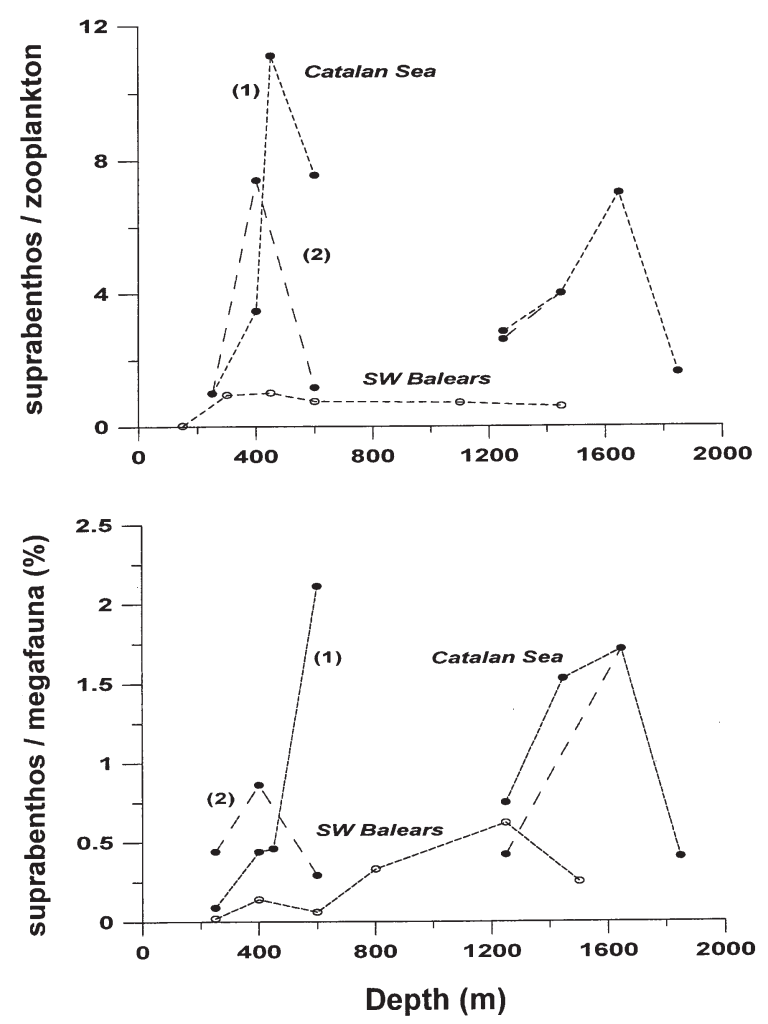

Fig. 9. Comparison of suprabenthos/zooplankton and suprabenthos/megafauna (fish and decapod) biomass ratios in the Catalan Sea and off the SW of Balearic Islands. (1) Data from the Catalan sea obtained in similar conditions to those described for the October 1996 cruise in the water column,

(2) data from 1996 and 1998 only (see text for details)

tial food sources here studied (only 1 positive correlation was detected between fish and suprabenthos). This may indicate that other compartments (not sampled in our study) than suprabenthos and mesozooplankton may serve as food sources to megafauna in the bathyal communities off the SW Balearic Islands. It is well documented that deep-water species exploit different compartments (plankton or benthos) as a function of depth (Gordon \& Mauchline 1990, Cartes $1994,1998)$. On the upper slope, fish prey on zooplankton (mainly euphausiids and copepods), while on the lower slope gelatinous plankton are the dominant food source in the diet of Alepocephalus spp., the dominant species in terms of biomass. In contrast, the benthos seems to support trophic chains at the mid-slope levels at least in the northwestern Mediterranean (i.e., in the Catalan Sea), as can be deduced from the higher abundance of infauna at intermediate depths in that area (Carpine 1970, Stora et al. 1999, author's unpubl. data), and as it has been shown for the Catalan Sea by means of a mass-balance model (Cartes \& Maynou 1998). Unfortunately, in our study it was not possible to adequately sample the macrozooplankton, such as pyrosomids, large medusae and salps, which contribute to the diet of Alepocephalus rostratus (Gordon \& Mauchline 1990, Carrasson 1994). The insufficient sampling of these organisms in our study is probably not only attributable to the mesh size used, but also to the fact that gelatinous macroplankton on the lower slope may be distributed above the $1.5 \mathrm{~m}$ height swept by our sledge. In the NE Atlantic, Hargreaves et al. (1984) detected peaks of gelatinous plankton up to 17 mab, on 900 to $1500 \mathrm{~m}$ soundings.

In our study, coupling was evidenced between suprabenthos-zooplankton and their possible food sources (fluorescence and particles in the water column). Only midwater zooplankton, sampled in the entire water column during May, was positively correlated to the fluorometer signal. In contrast, neither suprabenthos biomass nor near-bottom zooplankton coincided with higher signals in the fluorometer response. This may reflect a more rapid response to the vertical flux (primary production) by midwater organisms inhabiting the water column than for BBL organisms inhabiting the water column-sediment interface. These results suggest the existence of differences in response time for each compartment, but also that no direct link exists between primary production and biomass from the BBL fauna, which are almost exclusively caught at the 0 to $0.5 \mathrm{~m}$ sediment-water layer interface (Cartes 1998) at bathyal depths. Correlations with light transmission (inverse to particle concentration) seem to further support this argument. Thus, while midwater zooplankton in May was positively correlated with particle concentration (both along the entire water column and at $50 \mathrm{mab}$ ), zooplankton captured close to the bottom in October was positively correlated to particle concentration at 50 mab only. Therefore, the BBL zooplankton seems to depend only on food sources near the bottom (50 mab) in October 1996, while in May 1998 midwater zooplankton seems trophically dependent on vertical flux in all the water column. The zooplankton maxima at ca $400 \mathrm{~m}$ in May 1998 coincided with the maximum of particle concentration there, probably reflecting the crossing of a frontal oceanographic structure at that depth. Font et al. (1988) documented the existence of this permanent structure in the Catalano-Balearic Basin, which cuts across the seabed at depths of ca $400 \mathrm{~m}$. These oceanographic structures have been also described around the SW Balearic Islands (García-Ladona et al. 1996). The suprabenthos has also a negative correlation to particle concentration in the water column, also indicating low dependence on the vertical flux. In general, this interface fauna is not only supported (at least completely) by vertical flux, but it may be linked to advective fluxes and near-bottom deposition and resuspension processes. In this case, however, no significant 
correlations were detected to particle concentration at 50 mab.

In a wider context, other studies evidenced stronger coupling relating benthos (infauna) diversity with the vertical flux (surface pigment concentrations in this case: Watts et al. 1992) than that obtained between suprabenthos/ superficial food sources in our study. The time scale adopted may undoubtedly influence the results obtained. Thus, while Watts et al. (1992) adopted monthly to seasonal temporal scales and integrated small time scales, our near-simultaneous sampling of different trophic levels is probably below the response time expected by macrofauna to superficial food inputs, considering that the response time documented for meiofaunal-benthic communities to rapid phytodetritus sinking is overall $\sim 8 \mathrm{~d}$ (Graf 1989) at abyssal depths.

The size distributions of suprabenthos-zooplankton and megafaunal species followed different patterns in our study. While suprabenthos-zooplankton showed a high proportion of small sizes (recruits) in the October 1996 populations, all dominant megafaunal species (decapod crustaceans) showed a high proportion of small juveniles in May 1998. The pattern for suprabenthos-zooplankton species coincided with a high fluorescence response in October 1996, and this might imply a higher food supply for small juveniles in that period, conditioning also a higher recruitment success. However, possible relationships between fluorescence and phytoplankton productivity (food supply) must be taken with caution because the gradient of the fluorescence/chlorophyll relationship can vary according to phytoplankton species (McKee et al. 1999), and consequently also with annual phytoplankton succession. Within the suprabenthos-zooplankton species, Euphausia krohni and Boreomysis arctica directly exploit phytoplankton/phytodetritus (Casanova 1974, Cartes \& Sorbe 1998), and also showed a clear peak of recruits in October 1996 as a possible response to a higher food input. E. krohni is a mesopelagic species which may directly consume phytoplankton, while $B$. arctica is a non-migrating species distributed close to the sea-floor where it consumes phytodetritus. In a seasonal study effected in the Catalan Sea area, dinoflagellates occupied a considerable volume of the gut contents in $B$. arctica, whereas diatoms were poorly represented (Cartes \& Sorbe 1998), suggesting some size selectivity on the phytoplankton exploited by $B$. arctica. In the Balearic Islands, dinoflagellates reached their highest diversity and abundance at mid-autumn (Gomis et al. 1995), coinciding with the October 1996 cruise. Dinoflagellates regularly reach density maxima during the stratification period in the western Mediterranean (Estrada 1985), coinciding with the stratification conditions of the water-mass during our October 1996 sam- pling. This scenario seems consistent with a positive response reflected in B. arctica populations. After the rapid phytodetritus input from superficial waters to the deep-water seabed (100 $\mathrm{m} \mathrm{d}^{-1}$, Gage \& Tyler 1991), some peaks of recruits may be detected for suprabenthos-zooplankton species coupled with this matter flux. This possible response in recruit densities has been less clearly detected for the other dominant macrofaunal species studied. However, those species mainly exploited meiofauna: e.g., Rhachotropis caeca feeds on copepods and Munnopsurus atlanticus is indirectly linked to phytodetritus via benthic foraminiferans (Cartes et al. 2000). Responses by these species, although expected to be quick due to the rapid consumption of phytodetritus documented for foraminiferans (Gooday et al. 1992), do not seem as fast as expected in species that directly exploit phytoplankton/phytodetritus.

In conclusion, our comparative demographic data suggests that it does not seem adequate (at least only) to search for correlations between compartments, because different strategies and trophic levels are included within the BBL macrofauna, and autoecological studies are more appropriate. In the case of top trophic levels, here represented by megafaunal decapods, no direct response to superficial food inputs was detected. Coupling can also be expected to occur as a function of the macrofaunal size exploited (Cartes 1998), and in this case considerations not only on prey abundance, but also on prey size and mobility must be considered (Cartes 1998). Therefore it is not possible to establish the indirect effect of superficial production on high trophic levels at small-scale periods.

The SW Balearic Islands is an open area far away from the influence of the mainland (see map in Fig. 1). Despite the fact that no sediment data were obtained in our study, it is known that in the sampling area mud with biogenous material (foraminiferans: Orbulina universa) of planktonic origin is the dominant sediment throughout the slope (Emelyanov 1972, pers. obs. from the sledge samples). In general, this type of sediment is indicative of increasing oligotrophy (Sokolova 1972), also suggesting that the food chains are mainly dependent on the vertical flux in that area. In addition to this general scheme and based on comparison to the neighbouring well-known area of the Catalan Sea, some biological data also suggest that trophic webs in the SW of Balearic Islands are weakly supported by benthos. Calocaris macandreae, an infaunal deposit feeder decapod, is a key species in bathyal food webs in the Catalan Sea (Cartes 1994, Cartes \& Maynou 1998). C. macandreae only attained maximal densities of 3.7 ind. ha $\mathrm{ha}^{-1}$ in the SW Balearic Islands compared to 166.3 ind. ha ${ }^{-1}$ in the Catalan Sea, at similar depths, with the same trawl, and at similar periods - spring 
and autumn. This deposit feeder species probably has higher densities in the Catalan Sea due to the important influence of advective inputs of organic matter via submarine canyons in that area (Buscail et al. 1990). As deduced from Fig. 9 and assuming interannual variability (see 'Materials and methods'), the suprabenthos also reached lower densities in the SW Balearic Islands than in the Catalan Sea, even considering the limited number of samples available in the former area. A comparison of decapod trophic guilds in both areas evidenced the dominance of non-migrating macroplankton feeders of Plesionika spp. in the deep waters off the SW Balearic Islands assemblages (Maynou \& Cartes 2000). In summary, all these data suggest that trophic webs in the SW Balearic Islands are supported to a greater extent by plankton biomass, rather than by benthos. The SW Balearic Islands may constitute a scenario more similar to that suggested by Koslow (1997) for trophic webs in seamount open areas off SW Australia, where the diet and biomass of the dominant fish Hoplostethus atlanticus are mainly supported by plankton.

Acknowledgements. We wish to thank all participants in the cruises 'QUIMERA-1' and 'QUIMERA-2' on board RV 'García del Cid'. Both cruises were funded in the framework of the research project 'Deep-Sea Fisheries' (ref. FAIR-CT95-0655).

\section{LITERATURE CITED}

Baker ET, Lavelle JW (1984) The effects of particle size on the light attenuation coefficient of natural suspensions. J Geophys Res 89:8197-8203

Bulman CM, Koslow JA (1992) Diet and food consumption of a deep-sea fish, orange roughy Hoplostethus atlanticus (Pisces: Trachichthydae), off southeastern Australia. Mar Ecol Prog Ser 82:115-129

Buscail R, Pocklington R, Daumas R, Guidi L (1990) Fluxes and budget of organic matter in the Benthic Boundary Layer over the northwestern Mediterranean. Cont Shelf Res 10:1089-1122

Carpine C (1970) Ecologie de l'étage bathyal dans la Méditerranée occidentale. Mem Inst Oceanogr Monaco 2:1-146

Carrasson M (1994) Relaciones tróficas en las comunidades ícticas bentónicas (de 1000 a 2200 m) del Mar Catalán. PhD Thesis, Universidad Autónoma de Barcelona, Barcelona

Carrasson M, Matallanas J, Casadevall M (1998) Feeding strategies of deep-water morids on the Western Mediterranean. Deep-Sea Res I 44:1685-1700

Cartes JE (1994) Influence of depth and seasonality in the diet of the deep-water shrimp Aristeus antennatus along the slope (between 400-2300 m). Mar Biol 120:639-648

Cartes JE (1998) Feeding strategies and partition of food resources in deep-water decapod crustaceans in relation to depth (between 400-2300 m). J Mar Biol Assoc UK 78: 509-524

Cartes JE, Maynou F (1998) Food consumption by bathyal decapod crustacean assemblages in the western Mediterranean: predatory impact of megafauna and the food consumption - food supply balance in a deep-water food web. Mar Ecol Prog Ser 171:233-246
Cartes JE, Sorbe JC (1993) Les communautés suprabenthiques de la Mer Catalane (Méditerranée occidentale): données préliminaires sue la repartition bathymetrique et l'abondance des crustacés péracarides. Crustaceana 64(2): $155-171$

Cartes JE, Sorbe JC (1995) Deep-water mysids of the Catalan Sea: species composition, bathymetric and near-bottom distribution. J Mar Biol Assoc UK 75:187-197

Cartes JE, Sorbe JC (1998) Aspects of population structure and feeding ecology of the deep-water mysid Boreomysis arctica, a dominant species in western Mediterranean slope assemblages. J Plankton Res 20(12):2401-2411

Cartes JE, Company JB, Maynou F (1994) Deep water decapod crustaceans communities in the Northwestern Mediterranean: influence of submarine canyons and season. Mar Biol 120:221-230

Cartes JE, Elizalde M, Sorbe JC (2000) Contrasting lifehistories and secondary production by Munnopsurus atlanticus from two deep-water areas of the NE Atlantic and the W Mediterranean. Mar Biol 136:881-890

Casanova B (1974) Les euphaisiaces de Méditerranée (Systematique et et developpement larvaire. Biogéographie et Biologie. These, Université de Provence (Aix-Marseille I)

Emelyanov EM (1972) Principal types of recent bottom sediments in the Mediterranean Sea: their mineralogy and geochemestry. In: Stanley DJ (ed) The Mediterranean Sea: a natural sedimentation laboratory. Dowden, Hutchinson and Ross, Stroudsburg, p 355-386

Estrada M (1985) Deep phytoplankton and chlorophyll maxima in the Western Mediterranean. In: MoraitouApostolopoulou M, Kiortsis V (eds) Mediterranean marine ecosystems. NATO Conference Series: Ecology, Vol 8. Plenum Press, New York, p 247-278

Font J, Salat J, Tintoré J (1988) Permanent features of the circulation in the Catalan Sea. Oceanol Acta 9:51-57

Fredj G, Laubier L (1985) The deep Mediterranean benthos. In: Moraitou-Apostolopoulou M, Kiortsis V (eds) Mediterranean marine ecosystems. Plenum Press, New York, p 109-146

Gage JD (1994) Recruitment ecology and age structure of deep sea invertebrate populations. In: Young CM, Eckelbarger KJ (eds) Reproduction, larval biology, and recruitment of the deep sea benthos. Columbia University Press, New York, p 224-243

Gage JD, Tyler PA (1991) Deep sea biology: a natural history of organisms at the deep-sea floor. Cambridge University Press, Cambridge

García-Ladona E, Castellón A, Font J, Tintoré J (1996) The Balearic current and volume transports in the Balearic basin. Oceanol Acta 19: 489-497

Gomis C, Fernández de Puelles ML (1995) The phytoplankton cycle in the south-west of the Majorcan shelf (Balearic Islands): seasonal distribution. Rapp Comm Int Mer Médit $34: 207$

Gooday AJ, Levin LA, Linke P, Heeger T (1992) The role of benthic foraminifera in deep-sea food webs and carbon cycling. In: Rowe GT, Pariente V (eds) Deep-sea food chains and the global carbon cycling. Kluwer Academic Publishers, Dordrecht, p 63-92

Gordon JDM, Mauchline J (1990) Depth-related trends in diet of a deep-sea bottom-living fish assemblage of the Rockall Trough. In: Barnes M, Gibson RN (eds) Trophic relationships in the marine environment. Proc 24th Eur Mar Biol Symp. Aberdeen University Press, Aberdeen, p 439-452

Graf G (1989) Benthic-pelagic coupling in a deep-sea benthic community. Nature 341:437-439

Haedrich RL, Rowe GT, Polloni, PT (1980) The megabenthic 
fauna in the deep sea south of New England, USA. Mar Biol 57:165-179

Hargreaves PM, Ellis CJ, Angel MV (1984) An assessment of biological processes close to sea bed in a slope region and its significance to the assessment of sea bed disposal of radiactive waste. Rep Inst Oceanogr Sci 185:1-121

Hecker B (1990) Photographic evidence for the rapid flux of particles to the sea floor and their transport down the continental slope. Deep-Sea Res 37(12): 1773-1782

Hopper AG (1994) Deep-water fisheries of the North Atlantic Oceanic slope. NATO ASI Series. Kluwer Academic Publishers, Dordrecht

Joselson AB, Conley DJ (1997) Benthic response to a pelagic front. Mar Ecol Prog Ser 147:47-62

Jumars PA, Gallagher ED (1982) Deep-sea community structure: three plays on the benthic proscenium. In: Ernst WG, Morin JG (eds) The environment of the deep sea. Prentice Hall, Englewood Cliffs, p 217-255

Koslow JA (1997) Seamounts and the ecology of deep-sea fisheries. Am Sci 85:168-176

Lochte K, Turley CM (1988) Bacteria and cyanobacteria associated with phytodetritus in the deep sea. Nature 333: 67-69

Macpherson E (1977). Estudio sobre relaciones tróficas en peces bentónicos de la costa catalana. PhD Thesis, Universidad de Barcelona, Barcelona

Macpherson E (1979) Ecological overlap between Macrourids in the Western Mediterranean Sea. Mar Biol 53:149-159

Mauchline J, Gordon JDM (1985) Trophic diversity in deepsea fish. J Fish Biol 26:527-535

Maynou F, Cartes JE (1997) Estimation of daily ration on field in the deep-sea shrimp Aristeus antennatus. Mar Ecol Prog Ser 153:191-196

Maynou F, Cartes JE (1998) Daily ration estimates and comparative study of food consumption in deep-water decapod crustacean of the NW Mediterranean. Mar Ecol Prog Ser 171:221-231

Maynou F, Cartes JE (2000) Community structure of bathyal decapod crustaceans assemblages off the Balearic Islands (Southwestern Mediterranean: seasonal changes and regional patterns in zonation. J Mar Biol Assoc UK 50(8):789-798

McClatchie S, Millar R, Webster F, Lester PJ, Hurst R, Bagley N (1997) Demersal fish community diversity off New Zealand: is it related to depth, latitude and regional surface phytoplankton? Deep-Sea Res 44(4):647-667

McKee D, Cunningham A, Jones K (1999) Simultaneous mesurements of fluorescence and beam attenuation: instrument characterization and interpretation of signals from stratified coastal waters. Estuar Coast Shelf Sci 48: 51.58

Mees J, Jones MB (1997) The hyperbenthos. Oceanogr Mar Biol Annu Rev 35:221-255

Merrett NR, Haedrich, RL (1977) Deep-sea demersal fish and fisheries. Chapman \& Hall, London

Merrett NR, Marshall NB (1981) Observations on the ecology of deep-sea bottom living fishes collected off northwest Africa $\left(08^{\circ}-27^{\circ} \mathrm{N}\right)$. Prog Oceanogr 9:185-244

Miquel JC, Fowler SW, La Rosa J, Buat-Menard P (1994) Dynamics of the downward flux of particles and carbon in the open northwestern Mediterranean Sea. Deep-Sea Res 41:243-261

Editorial responsibility: Otto Kinne,

Oldendorf/Luhe, Germany
Moranta J, Stefanescu C, Massuti E, Morales-Nin B, Lloris D (1998) Fish community structure and depth-related trends on the continental slope of the Balearic Islands (Algerian Basin, western Mediterranean). Mar Ecol Prog Ser 171: 247-259

Pakhomov EA, Verheye HM, Atkinson A, Laubscher RK, Taunton-Clark J (1997) Structure and grazing impact of the mesozooplankton community during late summer 1994 near South Georgia, Antarctica. Polar Biol 18: 180-192

Pfannkuche O (1992) Organic carbon flux through the benthic communityin the temperate abyssal Northeast Atlantic. In: Rowe GT, Pariente V (eds) Deep-sea food chains and the global carbon cycling. Kluwer Academic Publishers, Dordrecht, p 183-198

Puig P, Palanques A (1998) Nepheloid structure and hydrographic control on the Barcelona continental margin, northwestern Mediterranean. Mar Geol 149:39-54.

Smith KL Jr (1992) Benthic boundary layer communities and carbon cycling at abyssal depths in the central North Pacific. Limnol Oceanogr 37(5):1034-1056

Sokal, RR, Rohlf FJ (1969) Biometry: the principles and practice of statistics in biological research. WH Freeman and Co, San Francisco

Sokolova MN (1972) Trophic structure of deep-sea macrobenthos. Mar Biol 16:1-12

Stefanescu C, Lloris D, Rucabado J (1992) Deep-living demersal fishes in the Catalan Sea (western Mediterranean) below a depth of $1000 \mathrm{~m}$. J Nat Hist 26:197-213

Stefanescu C, Morales-Nin B, Massutí E (1994) Fish assemblages on the slope in the Catalan Sea (Western Mediterranean): influence of a submarine canyon. J Mar Biol Assoc UK 74:499-512

Stora G, Bourcier M, Arnoux A, Gerino M, Le Campion J, Gilbert F, Durbec JP (1999) The deep-sea macrobenthos on the continental slope of the northwestern Mediterranean Sea: a quantitative approach. Deep-Sea Res I 46: 1339-1368

Tyler PA (1988) Seasonality in the deep sea. Oceanogr Mar Biol Annu Rev 26:227-258

Tyler PA, Campos-Creasy LA, Giles LA (1994) Environmental control of quasi-continuous and seasonal reproduction in deep-sea benthic invertebrates. In: Young CM, Eckelbarger KJ (eds) Reproduction, larval biology and recruitment of the deep-sea benthos. Columbia University Press, New York, p 158-178

Wang DP, Vieira ME, Salat J, Tintoré J, La Violette PE (1988) A shelf/slope frontal filament off the northeast Spanish Coast. J Mar Res 46:321-332

Watts MC, Etter RJ, Rex MA (1992) Effects of spatial and temporal scale on the relationship of surface pigment biomass to community structure in the deep-sea benthos. In: Rowe GT, Pariente V (eds) Deep-sea food chains and the global carbon cycling. Kluwer Academic Publishers, Dordrecht, p 245-254

Wenner EL, Boesch DF (1979) Distribution patterns of epibenthic decapod Crustacea along the shelf-slope coenocline, middle Atlantic Bight, USA. Bull Biol Soc Wash 3:106-133

Wishner KF, Gowing MM (1992) The role of deep-sea zooplankton in carbon cycles. In: Rowe GT, Pariente V (eds) Deep-sea food chains and the global carbon cycle. Kluwer Academic Publishers, Dordrecht, p 29-44

Submitted: February 17, 2000; Accepted: October 5, 2000

Proofs received from author(s): May 21, 2001 